\title{
Spatial Analysis of Agricultural Land Use Change and Farmers Adaptation to the Land Loss in Anyigba, Kogi State, Nigeria
}

\author{
1*TOKULA, AE; ${ }^{2}$ ADEKIYA, OA \\ ${ }^{I}$ Department of Geography and Environmental Studies, Faculty of Social Sciences, Kogi State University, Anyigba, Kogi State, Nigeria \\ ${ }^{2}$ Department of Geography and Environmental Management, Faculty of Social Sciences, University of Abuja, Nigeria \\ *Corresponding Author Email: tplarome@gmail.com
}

\begin{abstract}
This study examined the agricultural land use change and farmers adaptation to the land Loss by collecting data through structured questionnaire and aerial imagery. Cluster sampling was used to sample farmers in each cooperative and total of 173 registered farmers were selected for this study. The study revealed that Agricultural land decreases with an annual change rate of $-6.8 \mathrm{~km}^{2}(-60 \%)$ between 2001 and 2016, the total loss in annual rate from 1987 2016 was $-5.7 \mathrm{~km}^{2}(-55.9 \%)$. The result also revealed that in order to cope with the change in agricultural land, Majority (53.4\%) of the farmers did not depend solely on farming anymore but combined farming with other job opportunities that urbanization brought their ways. an exit from farming or reduction in production intensity in anticipation of future sale of land to developers is been term as a negative adaptation, the study therefore recommend that urban farmers should be encourage to continue in urban farming because most importantly, it provide the urban centres access to fresh vegetables among others.
\end{abstract}

\section{DOI: https://dx.doi.org/10.4314/jasem.v22i5.33}

Copyright: Copyright $(92018$ Tokula and Adekiya. This is an open access article distributed under the Creative Commons Attribution License (CCL), which permits unrestricted use, distribution, and reproduction in any medium, provided the original work is properly cited.

Dates: Received: 09 April 2018; Revised: 21 April: 2018; Accepted: 25 April 2018

Keyword: Urban Expansion, Urban Farmers, Land Use Change, Farmers Adaptation

The last century has experienced dramatic urban growth with the cities of the third world growing at an unprecedented rate. The number of people living in cities in the developing countries has at least quadrupled during the second part of the twentieth century (Kavitha et al., 2015; Kaifang et al., 2016; Owoeye, 2016). Globally, population increase is one of the most apparent agents responsible for this growth (Araya and Cabral, 2010; Owoeye, 2016). It is very interesting to know that the world urban population increased from 0.73 billion $(28.8 \%$ ) in 1950 , to 1.51 billion $(37.2 \%)$ in 1975 , and in 2009 , it further increased to 3.42 billion $(50.1 \%)$. It is further estimated to increase to 4.54 billion $(56.6 \%)$ in 2025 and 6.29 billion (69\%) by 2050 (UNDESA, 2010).

The peri-urban zoneis a transitional belt between the city and the countryside - a zone undergoing various kindsof transformations, where urban and rural features exist side by side (Simonet al., 2004). The term peri-urbanization refersto the process through which peri-urban areas physically and/or functionally get incorporated into the urbansystem (Graham, et al., 2004). It involves various transformations on the edges of large cities, such as transformation of existing rural settlements into urban settlements without necessarily displacing the ruralresidents (UNFPA, 2007) and changes in the structure of the peri-urban local economy, including changes in both sectorial composition of economic activities and labour force (Webster and Muller, 2002). Anyigba been the host community of Kogi State university has experiences changes in demography, social structure and land use as well as increased demand for land in peri-urban communities where indigenous and long-term settlers have depended on agriculture for centuries. In the face of the increase in urbanization and the loss in agrarian land area in Anyigba, how farmers cope or adapt to this loss in agrarian land remain unidentified.

In recent times, a small but growing body of research has drawn attention to "the changing interface between urban and rural spaces and the increasing interdependence between these two realms" (Lynch, 2005). Some of such research are studies on physical, environmental, socio-demographic, economic and other transformations in peri-urban areas resulting from urban growth (e.g. Rakodi, 1995; Lanjouw et al., 2001; Cavailhès and Wavresky 2003; Aberra and King 2005; Gough and Yankson, 2006; Ejaro and Abubakar 2013b;Tokula and Ejaro 2017b and Murali, et al., (2017). However, little is known about strategies adopted by peri-urban residents to adapt their livelihoods to these transformations, adaptation is a slow, usually unconscious modification of individual and social activity in adjustment to cultural 
surroundings, to adapt is to change in order to fit a situation better. The purpose of this paper is to help fill this gap by examining the agricultural land use change and farmers adaptation to the land Loss.

\section{MATERIAL AND METHOD}

The Study Area: The study area is Anyigba and is located at the south eastern direction, about $100 \mathrm{~km}$ from Lokoja the State capital of Kogi State in North Central Nigeria. The population of the area is approximately 71,323 (Tokula and Ejaro 2012a). Figure 1 shows the location of the study area which is geographically defined by longitude $7^{0} 9 \mathrm{E}^{1}$ and $7^{0} 12^{1} \mathrm{E}$ of the Greenwich meridian and latitude $7^{0} 28^{1} \mathrm{~N}$ and $7^{0} 32^{1} \mathrm{~N}$ of the equator, with an aerial extent of about 31.8 kilometer square and an average elevation of 354 meters above the sea level. The vegetation of the study area is predominantly guinea savannah type which is characterized by discontinuous canopy, shrubs and tall grasses giving the area a park appearance. The wooded savannah trees found in the area include economic trees such as locust bean, shear butter trees, timber, mahogany and obeche required for timber production. The majority of rural dwellers in the area is engage in peasant farming and other agricultural activities. The establishment of the Kogi State University, however, has boosted the administrative and commercial status of Anyigba, attracting industries and increasing trade and commerce in the area (Tokula and Ejaro, 2012a).

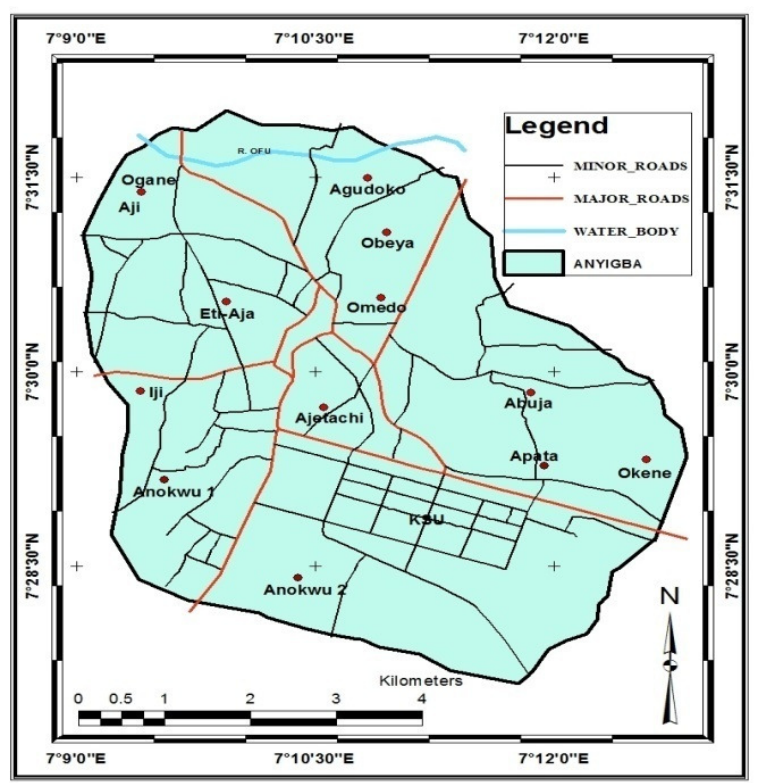

Fig 1. The study area

Data Collection: Data collection for this study was essentially through aerial imagery and social survey. The data on Land use land cover change, rate and extent of urban expansion in the area was obtained from geospatial technology (Remote sensing, GIS and GPS) application. Medium resolution satellite imageries were obtained from United State Geological Survey (USGS) and Global Land Cover Facility (GLCF). The ArcGIS 10.1 and IDRISI GIS Taiga version were used for the analysis of image. According to the land use classification scheme unsupervised and supervised approach with the maximum likelihood parameter (MLP) system was applied to improve the accuracy of the land use classification for the images for all the dates (1987, 2001 and 2016). The classification system utilized in this study is a slightly modified classification system for remotely sensed data as recommended by Anderson et al. (1976). From visual and digital interpretations of the satellite images, different land use and land cover categories were eminent in the study area and they are: Urban/Built-up, Vegetation, farmland and Bare Surface. Classification accuracy assessment is a general term for comparing the classification of geographical data that are assumed to be true to determine the accuracy of the classification process.

The primary data were collected through the use of structured questionnaire to elicit information from the respondents. The primary data covers the socioeconomic characteristics of the respondents, and their adaptation strategy as to the loss of agricultural land. The targeted population for the study are the urban and peri-urban farmers.

Cluster sampling is a sampling technique used when heterogeneous groupings are evident in study population. In this technique, the total population is divided into heterogeneous groups (or clusters) and a simple random sample of the groups is selected (Ahmed, 2009). Cluster sampling was used to sample farmers in each cooperative and that constitute the clusters. These clusters (or cooperative societies) involve farmers engaged in diverse agricultural activities ranging from food crop to animal rearing. This technique is however, chosen to enable farmers from different background and across different locations to be sampled. In order to have a wide coverage of farmers, all members in each identified cooperative society was sampled. The total number of registered famers in the various cooperatives in the study area is 173 and this figure is considered as reasonable enough to be adopted as the sample for the study.

In analyzing the social survey, the contents of the filled questionnaires were transferred onto a coding sheet prepared using a coding guide. The contents of the filled coding sheets is then analyzed using descriptive statistics. 


\section{RESULT AND DISCUSSION}

Demographic and Socioeconomic profile of respondents: Data on the demographic and socioeconomic characteristics of respondents are shown in Table 1. Socioeconomic data are essential factors that determine people's involvement and participation in agricultural activities. This is because it shows the level of education attained by the people, the major occupation engaged in and the age bracket which can have influence on the level of their participation in agricultural activities. The socioeconomic data assessed here include sex, occupation, and education, farming experience and income level of the people the urban and peri-urban farmers. The educational status of respondents as displayed in Table 1 showed that $26 \%$ of the respondents had no formal education, $15 \%$ had only primary education, $37 \%$ had secondary education and $22 \%$ had tertiary education. The finding is in disagreement with the work of Gwary et al., (2011) when they reported that majority (46\%) of the respondents (farmers) have tertiary education in their research on analysis of entrepreneurial agricultural activities of youths in Michika Local Government Area of Adamawa.

On the other possible occupation of the farmers apart from core farming, the result showed that a significant number of the respondents were involved in other occupations to diversify their sources of income. The result obtained indicated that $28.3 \%$ were involved in farming alone; $26 \%$ were involved in farming and petty trading; $15.6 \%$ were both involved in large business and farming and 15\% practiced farming and artisan while $15 \%$ were involved in civil service job and farming.

Furthermore, on the result on years of farming of the respondents, the result in Table 1 showed that $8.1 \%$ of the farmers had 1-10 years of experience; $18.5 \%$ had 11-15 years of experience; $8.1 \%$ had $16-20$ years of experience while $22.5 \%$ had $21-25$ years of experience, the result showed that majority $(37 \%)$ of the respondents had 31 years and above of farming experience. This is in agreement with Gwaryetal (2011) who reported that majority (45\%) of the respondents are into farming greater than 7 years. This may be attributed to the fact that, they may have realised a lot of economic benefits from farming. This is fascinating because the farmers will be able to manage the problem posed by the shortage of farmland and other challenges that affect agriculture.

On monthly income, the study further revealed that $52 \%$ earned above $\$ 40,100$ and only $6.4 \%$ earned less than $\$ 20,000$. The urban farmers income is necessary because it gives them the purchasing power to buy the scarce and costly land.

Table 1. Demographic and Socioeconomic profile of respondents

\begin{tabular}{|lcl|}
\hline Variable & Frequency & Percentage \\
\hline Sex & 127 & 73.4 \\
Male & 46 & 26.6 \\
Female & & \\
Educational Status & & 26.0 \\
No formal education & 45 & 15.0 \\
Primary education & 26 & 37.0 \\
Secondary & 64 & 22.0 \\
Tertiary education & 38 & \\
Occupation & & 28.3 \\
Farming only & 49 & 15.0 \\
Civil servant \& farming & 26 & 26.0 \\
Trading \& farming & 45 & 15.6 \\
Business \& farming & 27 & 15.0 \\
Artisan \& farming & 26 & \\
Farming experience (years) & 8.1 \\
1-10 years & 14 & 18.5 \\
11-15 years & 32 & 8.1 \\
16-20 years & 14 & 22.5 \\
21-25 years & 39 & 5.8 \\
26-30 years & 10 & 37 \\
31years and Above & 64 & \\
Income Level per month (N) & 6.4 \\
<N20,000 & 11 & 28.3 \\
N20,000 - N30,000 & 49 & 13.3 \\
N30,100 - N40,000 & 23 & 52 \\
N40,100 and Above & 90 & \\
\hline
\end{tabular}

Land Use Land Cover Change: The result in Table 2 and Figure 2 show the classified image of Anyigba with five (5) distinct types of land use. The farmland in Anyigba are represented by lemon color, in 1987 occupied $10.2 \mathrm{~km}^{2}$ and this covered $29.9 \%$ of the land use area; built-up land are represented by red color and it occupied $3.4 \mathrm{~km}^{2}$ representing $10 \%$; bare surface are represented by sahara sand color and it was $8.4 \mathrm{~km}^{2}$ representing $24.6 \%$, while vegetation are represented by green color and it was $12.1 \mathrm{~km}^{2}$ representing $35.5 \%$ of the total land area. In 2001, the farmland occupied $11.3 \mathrm{~km}^{2}$ representing $33.1 \%$ of the total land area; built-up occupied $5.2 \mathrm{~km}^{2}$ representing $15.2 \%$; vegetation occupied $8.5 \mathrm{~km}^{2}$ representing $25 \%$, while bare surface occupied $9.1 \mathrm{~km}^{2}$ representing $26.7 \%$ of the total land area. In 2016, the farmland occupied 4.5 $\mathrm{km}^{2}$ representing $13.2 \%$ of the total land area; built-up occupied $15.2 \mathrm{~km}^{2}$ and it covered $44.6 \%$; vegetation occupied $4.3 \mathrm{~km}^{2}$ representing $12.6 \%$, while bare surface occupied $10.1 \mathrm{~km}^{2}$ representing $29.6 \%$ of the total land area. This may be due to the fact that the city was just moving away from the traditional setting where farming seems to form the basis for living and the significant rapid urban growth could be attributed to the establishment of Kogi State University in 1999. The changes observed in land uses mostly on the increase in built-up in the study period is attributed to the increase in investments, the influx of students and increase in staff strength of the various institutions in 
the study area. Hence, increase in the construction of buildings to accommodate the increasing human population and administrative structures that have resulted in the consumption of other land uses. This is in agreement with the work of Ejaro and Abdullahi (2013a) in Suleja Local Government Area when they reported that the major factors responsible for the land use and land cover changes in the study area are urbanization and population dynamics. The result also substantiates the findings of Oyinloye, (2013) who reported direct relationship between rapid urban growth and factors such as creation of states and local governments; and sitting of universities, polytechnics, colleges of education, commercial centres, industrial centres, tourism resorts and population influx in Nigeria.

Table 2: Land use Land Cover table for Anyigba Town

\begin{tabular}{|l|l|l|l|l|l|l|}
\hline $\begin{array}{l}\text { Land use } \\
\text { type }\end{array}$ & $\begin{array}{l}1987 \\
\left(\mathrm{~km}^{2}\right)\end{array}$ & $\%$ & $\begin{array}{l}2001 \\
\left(\mathrm{~km}^{2}\right)\end{array}$ & $\%$ & $\begin{array}{l}2016 \\
\left(\mathrm{~km}^{2}\right)\end{array}$ & $\%$ \\
\hline Farmland & 10.2 & 29.9 & 11.3 & 33.1 & 4.5 & 13.2 \\
Vegetation & 12.1 & 35.5 & 8.5 & 25.0 & 4.3 & 12.6 \\
Built up & 3.4 & 10.0 & 5.2 & 15.2 & 15.2 & 44.6 \\
Bare Surface & 8.4 & 24.6 & 9.1 & 26.7 & 10.1 & 29.6 \\
Total & 34.0 & 100 & 34.1 & 100 & 34.1 & 100 \\
\hline
\end{tabular}

Source: Analysed Satellite Image

Extent and Rate of Urban Expansion in Anyigba: As shown in Table 3. The built-up increased from $1.8 \mathrm{~km}^{2}$
(52.9\%) between 1987 and 2001 to $10 \mathrm{~km}^{2}(192.3 \%)$ between 2001 and 2016 resulting in $11.8 \mathrm{~km}^{2}(347.1 \%)$ as the overall urban growth between $1987-2016$. Anyigba witnessed change rates of $0.12 \mathrm{~km}^{2}(3.7 \%)$ from $1987-2001$ and $0.7 \mathrm{~km}^{2}(12.8 \%)$ between 2001 - 2016. The entire study period (1987 to 2016) recorded an annual urban change rate of $0.4 \mathrm{~km}^{2}$ $(12 \%)$. Agricultural land decreases with an annual change rate of $-6.8 \mathrm{~km}^{2}(-60 \%)$ between 2001 and 2016, the total loss in annual rate between $1987-2016$ was $-5.7 \mathrm{~km}^{2}(-55.9 \%)$ for agricultural land.

The increase in the rate of change in built-up area corresponds with the negative rate of change of other land use classes identified in table 3. This suggests increased urbanization against decreasing other land uses. It is noteworthy that the decreasing rates of other land use classes also reflect human activities and urban expansion. This is in agreement with Mohammed, (2015) who reported that gradual reduction in agricultural land and natural forest can be attributed to the constant conquest by built - up land and bare surfaces. Allen and Lu, (2003) Reported that urban expansion has been criticized for eliminating agricultural lands, spoiling water quality, and causing air pollution.

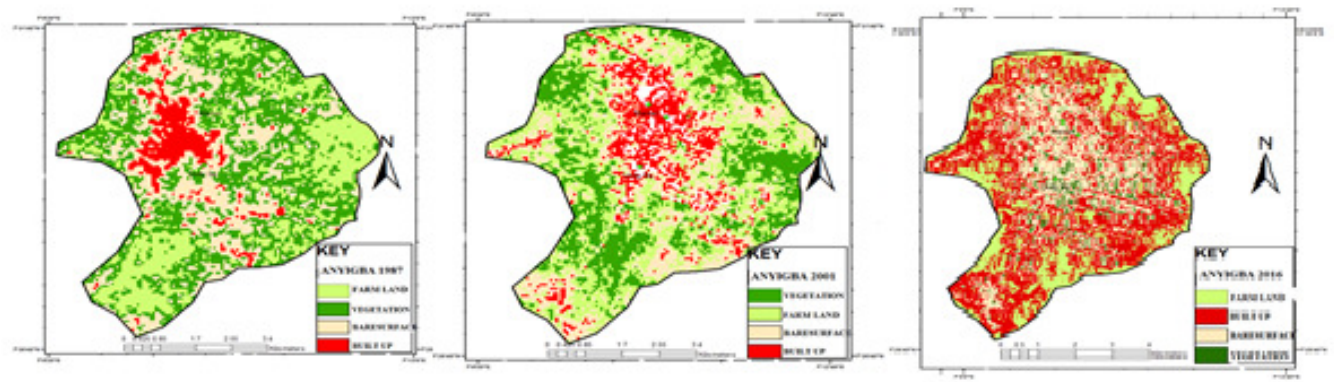

Fig 2. Land use classification of Anyigba as of 1987, 2001 and 2016

Table 3: Rate of Change in Urban growth between 1987-2016

\begin{tabular}{|l|l|l|l|l|l|l|l|l|l|}
\hline Land use & 1987 & 2001 & 2016 & \multicolumn{2}{|l|}{$1987-2001$} & \multicolumn{2}{|l|}{$2001-2016$} & \multicolumn{2}{|c|}{$1987-2016$} \\
\cline { 5 - 10 } Types & $\mathrm{Km}^{2}$ & $\mathrm{Km}^{2}$ & $\mathrm{Km}^{2}$ & $\mathrm{~km}^{2}$ & $\%$ & $\mathrm{~km}^{2}$ & $\%$ & $\mathrm{~km}^{2}$ & $\%$ \\
\hline Built Up & 3.5 & 5.2 & 15.2 & 0.12 & 3.7 & 0.7 & 12.8 & 0.4 & 12 \\
Farm land & 10.2 & 11.3 & 4.5 & 1.1 & 10.8 & -6.8 & -60.0 & -5.7 & -55.9 \\
\hline
\end{tabular}

Source: Analysed Satellite Image

Table 4: Adaptation/Coping Strategy to Loss in Farmland

\begin{tabular}{|lll|}
\hline Variable & Freg. & $\%$ \\
\hline \multirow{3}{*}{ Change in farming system } & Adaptation/Coping Strategy & \\
Livelihood diversification from farming & 43 & 26.3 \\
Diversification from cropping to livestock rearing & 87 & 53.4 \\
Move farther away from town & 5 & 3.1 \\
& 28 & 17.2 \\
Yes & Experience of Food deficit & 76.7 \\
No & 125 & 23.3 \\
& 38 & 23.3 \\
Not Applicable & Adaptation or Coping with food Deficit & 73.6 \\
Food purchase & 38 & 2.5 \\
Donor food aid & 120 & \\
\hline
\end{tabular}


Table 5. Challenges of urban farmers

\begin{tabular}{|l|l|l|}
\hline Variable & Frequency & \% \\
\hline Credit facilities & 67 & 38.7 \\
Problem of fertilizer availability & 36 & 20.8 \\
Farming tools & 26 & 15.0 \\
Costly nature of land & 19 & 11 \\
No extension workers to train the farmers & 8 & 4.6 \\
No Access to Improved crop yield variety & 06 & 3.5 \\
Pest and diseases & 04 & 2.3 \\
No knowledge on improved Agronomic practices & 04 & 2.3 \\
No dam for Irrigation & 02 & 1.2 \\
Post harvest handling & 01 & .6 \\
\hline Total & $\mathbf{1 7 3}$ & $\mathbf{1 0 0 . 0}$ \\
\hline
\end{tabular}

Source: Author's field work (2016)

Farmers Adaptation to Agricultural Land Loss: One indicator of the impacts of urbanization on agriculture is the adjustment that farmers make in their farming activities. Table 4shows the result on how farmers in the area adapt or cope with change in agricultural land. The study showed that in order for the farmers to adapt to the change in agricultural land, $26.3 \%$ of the respondents claimed they changed their farming system by no longer practicing bush fallowing (as a result of the shortage in land); applied animal manure to their farms before cultivation (to argument the soil for improved yield) and practicing multiple cropping, the farmers were also able to control pest and diseases such as the use of improved crop varieties, crop resistant variety and fast growing crop varieties. The result also revealed that in order to cope with the change in agricultural land, Majority (53.4\%) of the farmers did not depend solely on farming anymore but combined farming with other job opportunities that urbanization brought their ways. Livelihood diversification is an adaptation strategy in which periurban residents engage in multiple occupations, often with small-scale farming being one of them. This study agrees with Charles et al., (2015) who also reported that growth of urban areas over time has resulted in changes in livelihood strategies, with the shift from agriculture to non-agricultural activities being the most evident. However an exit from farming or reduction in production intensity in anticipation of future sale to developers is been term as a negative adaptation.

Another way farmers in the area adapt to change in agricultural land is the movement of farmers to areas where they are able to have access to available land. This is shown in Table 3 where $17.2 \%$ of the farmers moved farther from the town (city centre) to the urban fringe in order to get land for farming. The study also showed that $3.1 \%$ shift from cropping to livestock rearing. Livestock rearing is another adaptation strategy in which the urban farmers shift towards livestock production, which does not require as much land as crop farming.
The study further revealed that $76.7 \%$ (Table 3 ) of the respondents indicated that their family experienced food deficit, while $23.3 \%$ alleged they did not experience food deficit throughout the year. This is in agreement with NigatuRegassa (2011) when he reported that about $54 \%$ of the households were facing mild to severe food insecurity.Idachaba, (2004) described food security as the ability of individuals and households (especially the rural and urban poor) to meet staple food needs all year round. On how the families adapt or cope with food deficit, the result presented in Table 3 showed that $73.6 \%$ bought foodstuffs from the market during the months of food shortage; $23.3 \%$ do not experience food deficit all through the year while $2.5 \%$ receive food from donors (most people in this category are widowed and orphans).

Problem of Urban Farmers: Table 5 gives information on the challenges faced by urban farmers in the study area. It showed that $38.7 \%$ of the respondents complained of lack of access to credit facilities; $20.8 \%$ had issues with the availability of fertilizer; $15 \%$ complained of making use of crude farming tools, the same findings was observed by Adebayo and Adeola (2008) in Ibaji Local Government, Kogi State when they reported that rice farming is a major activity among the farmers but its production is mainly in the hands of small-scale resource poor farmers who depend heavily on the use of traditional technologies resulting in low productivity. Furthermore, $11 \%$ of the farmers complained of costly nature of land in the area while $4.6 \%$ complained of no access to extension workers. The study also revealed that $3.5 \%$ of the respondents complained of no access to improved crop yield variety, $2.3 \%$ complained of the problem of pest and diseases, another $2.3 \%$ complained of lack of knowledge on improved agronomic practices, $1.2 \%$ complained of no dam for irrigation while insignificant $0.6 \%$ complained of post-harvest handling. 
The result presented in Table 4 simply means that farmers in the selected communities are faced with diverse problems that need to be addressed by government for improved agricultural activities cum productivity. The farmers need government intervention in food production activities which can go a long to combat the menace of food crisis.It is expected that production inputs such as fertilizer, herbicides, pesticides, and improved seeds could be provided through institutional sources in good time, in enough quantities and affordable costs. Such institutions could include Ministries of Agriculture at federal and states levels, the local governments, research institutes, NGOs and organized farmers group/associations to bails out farmers' weak links in these production essentials. This is in agreement with Lamidi and Wasiu (2013), who reported that scarcity of farm machinery, poor infrastructural facilities, access to credit, non-affordable and secure access to complementary farm inputs and lower efficiency and capacity of public sector for implementing policy are the problem faced by farmers.

Conclusions: Anyigba is a university community and the centre of Kogi East with huge population. The rapid growing economy has resulted in an expansion in urbanization and the influx of migrants from rural to the urban area. The present study has documented that there is comparably high level household food insecurity among the study population. It is also seen that households in the study areas employ a variety of principal and complementary coping strategies ranging from Livelihood diversification; movement of farmers to areas where they are able to have access to available land. The study therefore recommend that urban farmers should be encourage to continue in urban farming because most importantly, it provide the urban centres access to fresh vegetables among others.

\section{REFERENCES}

Aberra, E; King, R (2005). Additional Knowledge of Livelihoods in the Kumasi Peri-urban Interface, Ashanti Region, Ghana. A project report (Boafo Ye Na project) for Development Planning Unit (DPU), University College London, UK..

Adebayo, OO; Adeola, RG (2008). Sources and Uses of Agricultural Credit by Small Farmers in Surulere L.G.A of Oyo State. J. Anthro. 10(4): 313-314

Allen, J; Lu, K (2003). Modeling and Prediction of Future Urban Growth in the Charleston Region of South Carolina: A GIS-Based Integrated Approach. J. Con. Eco.. 8 (2) 2
Cavailhès, J; Wavresky, P (2003). Urban influences on peri-urban farmland prices. Euro. Rev. of Agri. Econs. 30(3): 333-357

Ejaro, SP; Abdullahi, U (2013a). Spatiotemporal Analyses of Land Use and Land Cover Changes in Suleja Local Government Area, Niger State, Nigeria. J. of Env. and Earth Sci. 3 (9):72-82.

Ejaro, SP; Abubakar H (2013b). Challenges of rapid urbanization on sustainable development of Nyanya, Federal Capital Territory, Abuja, Nigeria. J. Appl. Sci. Environ. 17 (2): 299-313

Gough, K; Yankson, P (2006). Conflict and Cooperation in Environmental Management in Peri-urban Accra. In D. Simon, D. McGregor, \& D. Thompson (Eds.). The periurban interface: approaches to sustainable natural and human resource use. London: 564.

Graham, J; Gurian, P; Corella-Barud, V; Avitia, R (2004). Peri-urbanization and in-home Environmental Health Risks: The Side Effects of Planned and Unplanned Growth. Int. J. of Hygiene and Env. H. 207(5): 447-454.

Gwary, MM; Kwaghe, PV; Ja'afar-Furo, MR; Dennis (2011). Analysis of Entrepreneurial Agricultural Activities of Youths in Michika L.G.A Adamawa State, Nigeria. J. of Dev. and Agri. Econs. 3(3): 91-97

Idachaba, F (2004). Food Security in Nigeria: Challenges Under Democratic Dispensation. Paper presented at Agricultural and Rural Management Training Institute (ARMTI). ARMTI Lecture, Ilorin. 1-23.

Kaifang, S; Yun, C; Bailang, Y; Tingbao, X; Linyi, L; Chang, H; Rui, L; Zuoqi, C; Jianping, W (2016). Urban Expansion and Agricultural Land Loss in China: A Multistage Perspective. J. of $\begin{array}{lll}\text { sustainability. } & \text { 8(8): } & 790 .\end{array}$ doi: $\underline{10.3390 / \text { su } 8080790}$

Kavitha, A; Somashekar, RK; Nagaraja, BC (2015). Urban expansion and Loss of Agriculture Land A case of Bengaluru city. Int. J. of geo. and geosciences. 5 (3). 492-498.

Lamidi, WA; Akande, LO (2013). A Study of Status, Challenges and Prospects of Agricultural 
Mechanization in Osun State, Nigeria. J. of Edu., Arts and Hum. 1 (1): 001-008.

Lanjouw, P; Quizon, J; Sparrow, R (2001). Nonagricultural earnings in peri-urban areas of Tanzania: Evidence from Household Survey Data. J. Food Pol. 26(4): 385-403.

Lynch, K (2005). Rural-urban Interaction in the Developing World. Int. J. of Urb. and Reg. Research. 36(6): 1306-1325.

Murali, KG; Irshad, M; Swamikannu, N; Anthony, W; Carl, JL (2017). Urban Sprawl and Adverse Impacts on Agricultural Land: A Case Study on Hyderabad, India. Remote sens. 9. 1136.

Nigatu, R (2011). Small Holder Farmers Coping Strategies to Household Food Insecurity and Hunger in Southern Ethiopia. Eth. J. of Env. St. and Mng. 4 (1): 39-48.

Owoeye, JO (2016). A Study on Environmental Habitability of Core Residential Neighborhood in Akure, Nigeria. International J. of Phy. and Hum. Geo.. 4 (1): 20-33.

Oyinloye, MA (2013). Geospatial Analysis of Urban Growth- The Case of Akure, Nigeria XIV Ame. J. of Soc. Issues and Hum. 3 (4): 200 - 212.
Rakodi, C (1995). Poverty lines or household strategies? A review of conceptual issues in the study of urban poverty. Hab. Int. 19 (4): 407-426.

Simon, D; McGregor, D; Nsiah-Gyabaah, K (2004). The Changing Urban-rural Interface of African Cities: Definitional Issues and an Application Kumasi, Ghana. J. Environ Urb. 16 (2): 235-247.

Tokula, A; Ejaro, SP (2012a). Dynamics of Land use/Land Cover Changes and its Implications on Food Security in Anyigba, North Central Nigeria. Con. J. Envtal. Std.. 7 (1): 42-52.

Tokula, AE; Ejaro, SP (2017b). The Impact of Urban Expansion on Agricultural Land and Crop Output in Ankpa, Kogi State, Nigeria. J. of Landscape Arch. 1 (1): 1-13.

UNFPA (2007). State of world population 2007: Unleashing te potential of urban growth. Retrieved from http://www.unfpa.org/swp/2007/english/chapter_ 4/print/chapter_4.html

Webster, D; Mullefr, L (2002). Challenges of PeriUrbanization in the Lower Yangtze Region: The case of the Hangzhou-Ningbo Corridor. A paper for the Asia/Pacific Research Center, Stanford University. 